\title{
NICHOLAS GEORGESCU-ROEGEN, DEVELOPMENT ECONOMIST
}

\author{
BY CARLOS EDUARDO SUPRINYAK*
}

\begin{abstract}
Accounts of Nicholas Georgescu-Roegen's career usually focus on his pioneer contributions to mathematical economics during the 1930s and his later conversion to a critical approach to economic theory anchored on the entropy law. These disparate moments, however, were connected by Georgescu-Roegen's strong attraction to the study of problems afflicting less developed societies. This began with his work on the agrarian economy of his native Romania, in the late 1940s, under the auspices of Harvard's Russian Research Center. Thenceforth, he embarked on a journey that spawned his early interest in Leontief-type linear models, an extended tour of Southeast Asia commissioned by Vanderbilt University's Graduate Program in Economic Development, and several visits to Brazil during the 1960s. The paper highlights these lesserknown aspects of Georgescu-Roegen's trajectory, examining how he built on neo-populist writings from the early 20th century to construct an alternative to the mainstream emphasis on industrialization policies.
\end{abstract}

* Associate Professor at Cedeplar, Federal University of Minas Gerais (UFMG). Email to: suprinyak@cedeplar.ufmg.br.

This "preprint" is the peer-reviewed and accepted typescript of an article that is forthcoming in revised form, after minor editorial changes, in the Journal of the History of Economic Thought (ISSN: 1053-8372), issue TBA. Copyright to the journal's articles is held by the History of Economics Society (HES), whose exclusive licensee and publisher for the journal is Cambridge University Press.

(https://www.cambridge.org/core/journals/journal-of-the-history-of-economic-thought) This preprint may be used only for private research and study and is not to be distributed further.

The preprint may be cited as follows:

Suprinyak, Carlos Eduardo. Nicholas Georgescu-Roegen, Development Economist. Journal of the History of Economic Thought (forthcoming). Preprint at SocArXiv, osf.io/preprints/socarxiv 


\section{Introduction}

Discussions of the place occupied by Nicholas Georgescu-Roegen in the history of economics usually focus on two aspects: his contributions to mathematical economics, either refining or criticizing the neoclassical theories of choice and production; and his later studies on what he termed bioeconomics, a novel approach to the joint study of economics and biology emphasizing the importance of dialectical concepts and the entropy law. In their obituary note for the Economic Journal, Maneschi \& Zamagni (1997) argue that his "scientific activity can be divided into two broad phases," separated by a clear watershed around 1965-66. This notion was partially fostered by Georgescu-Roegen himself - who spoke of a "fundamental change in my orientation as an economist" happening at around that time (Georgescu-Roegen 1976, p. ix) - and later popularized by some of his followers (Miernyk 1990). Even scholars who dispute the accuracy of this narrative are mostly interested in reestablishing the coherence between these two moments in Georgescu-Roegen's career, without questioning whether they actually exhaust his contributions or faithfully portray his intellectual trajectory (Mirowski 1992; Gowdy \& Mesner 1998; Bobulescu 2012; Missemer 2013).

In this paper, I wish to call attention to a somehow neglected aspect of GeorgescuRoegen's life and work: his longstanding engagement with development economics. The notion of development, of course, was congenial to his bioeconomics project, but at this later stage of his career he spoke of development in rather unconventional terms, as the search for viable technologies that could guarantee the preservation of the human species (Missemer 2017). Throughout the 1950s and 1960s, however, Georgescu-Roegen had been closely involved with the mainstream of development economics, discussing the theoretical groundwork that sustained this burgeoning field and the concrete limitations of foreign aid policies derived from it. Maneschi \& Zamagni (1997, p. 696) recognize the importance of his works on agrarian economics, "which reflected his attempt to understand the nature of underdevelopment in his native country," but refrain from discussing the topic at length. Whereas Bobulescu (2012) brings this aspect to the forefront of her analysis, she attributes Georgescu-Roegen's interest in the study of economic development to the joint influence of his mentor, Joseph Schumpeter, and of his personal experiences working for the Romanian government during the 1930s and 1940s.

While not denying the relevance of these factors, my purpose is to show how Georgescu-Roegen's academic trajectory overlapped in important ways with the emergence of 
development economics as a scholarly field. Even though his publication record may not illustrate this very clearly, a careful analysis of his personal papers reveals how GeorgescuRoegen consistently strove to position himself as a student of the problems associated with economic development, being recognized as such by many of his contemporaries. His interest in the subject was nurtured even further by his affiliation to Vanderbilt University, which operated a pioneering Graduate Program in Economic Development since the mid-1950s. The paper will thus contribute to a better understanding of Georgescu-Roegen's intellectual endeavors, exploring his career path and how he related to contemporary trends within the economics discipline.. Moreover, his idiosyncratic case will also serve to further exemplify the "fundamental eclecticism of development economics" (Alacevich \& Boianovsky 2018, p. 8) during the heyday of the field.

\section{Peasant Societies and Leontief Matrices}

In his autobiographical writings, Georgescu-Roegen made frequent reference to his "12year exile" in Romania between 1936 and 1948, a period he described as an "intellectual hibernation" that only ended with his return to Harvard after a dramatic escape from the Communist regime then ruling his native country (Georgescu-Roegen 1988). Some commentators regard this so-called 'exile' as a moment in which important ideas about the nature of the economic process, and the role of institutional factors therein, were planted in GeorgescuRoegen's mind, to bear fruit much later in his career (Gowdy \& Mesner 1998, pp. 139-40; Bobulescu 2012, pp. 629-33). Such effects, however, were much more immediate than usually recognized. Upon his return to Harvard, instead of going back to the mathematical explorations of consumer theory that had occupied him during his visit in 1934-36, Georgescu-Roegen was recruited by his old acquaintance Wassily Leontief to work on two different ventures. ${ }^{1}$ One of them was the Harvard Economic Research Project, co-directed by Leontief and Edward Mason, and dedicated to improving the tools of input-output analysis created by the former. His other assignment was at the recently created Russian Research Center, an interdisciplinary unit focused

\footnotetext{
${ }^{1}$ Memorandum from Clyde Kluckhohn, July 19, 1948; Nicholas Georgescu-Roegen Papers, David M. Rubenstein Rare Book and Manuscript Library, Duke University [henceforth NG-RP], Box 23, Folder 'Harvard University - Russian Research Center'.
} 
on the "study of Russian institutions and behavior," using the social sciences to contribute to the "scientific and scholarly understanding of the Soviet world". ${ }^{2}$ The Center included a section in charge of economic studies, also headed by Leontief, who commissioned Georgescu-Roegen to write a small monograph on the topic "Economic Developments in Rumania After the War". 3

Even though he stayed for only one year at Harvard, these two engagements proved very influential in the relaunching of Georgescu-Roegen's academic career during the 1950s. His work with the Harvard Economic Research Project led to multiple papers elaborating the mathematical properties of Leontief-type models (Georgescu-Roegen 1950, 1951a, 1951b). Georgescu-Roegen participated in the famous 1949 Cowles Commission conference on Activity Analysis of Production and Allocation, contributing three papers to the proceedings, and receiving credit from Tjalling Koopmans (1951) for helping organize the conference volume. ${ }^{4}$ One of these papers contained a proof of the so-called non-substitution theorem, a result demonstrated independently by Samuelson in a contribution to the same conference, but to which Georgescu-Roegen claimed priority for having already presented his findings in a 1949 meeting at Harvard (Georgescu-Roegen 1992, pp. 134-5).

If the Economic Research Project thus allowed Georgescu-Roegen to reconnect with frontier research in mathematical economics, his work at the Russian Research Center required a quite different set of skills. As Leontief told him, he could contribute to the center as "an experienced and qualified witness of the events and developments which took place in Rumania since the end of the war." ${ }^{.5}$ In an internal report from January 1949, his study of the Romanian economy was thus summarized:

\footnotetext{
${ }^{2}$ Clyde Kluckhohn, Russian Research at Harvard, reprinted from World Politics, vol. 1, no. 2, pp. 267-272, January 1949; NG-RP, Box 23, Folder 'Harvard University - Russian Research Center'. ${ }^{3}$ Letter from Wassily Leontief to Nicholas Georgescu-Roegen, May 26, 1948; NG-RP, Box 23, Folder 'Leontief, Wassily 1948-49, 64-74'.

${ }^{4}$ For a discussion of the importance of the 1949 Activity Analysis conference, see Düppe \& Weintraub (2014).

${ }^{5}$ Letter from Wassily Leontief to Nicholas Georgescu-Roegen, May 26, 1948; NG-RP, Box 23, Folder 'Leontief, Wassily 1948-49, 64-74'.
} 
Part I: Main problems of contemporary Rumania: population, agrarian situation, industrial development, financial policy, foreign trade, national income and standard of living, international position. Part II: Economic changes after the War: Economic burdens of the Armistice, economic agreements with the U.S.S.R., monetary reform, financial reforms, nationalization, agricultural and industrial production, national income and individual incomes. ${ }^{6}$

Georgescu-Roegen was fit for the task, given his recent experience working for the Romanian Central Statistical Institute, the Institute of Business Cycle Research, the Ministry of National Economy and, finally, as general secretary of the Armistice Commission (GeorgescuRoegen 1993). More importantly, his background had put him in contact with burgeoning arguments about policies and strategies for the economic development of backward areas in East Central Europe. As shown in the classic study by Joseph Love (1996, pp. 25-98), these arguments were especially vigorous in interwar Romania. One of their central underlying themes was the notion of dualism: the existence of a dual socioeconomic structure in backward societies, comprising a modern industrial complex alongside a large traditional agricultural sector, the latter still shaped by the habits and institutions of peasant life. In Romania, as in Russia and other parts of East Central Europe, the dispute concerned the adequate attitude toward the peasantry. Marxian analysts viewed the peasants as a remnant of pre-capitalist modes of production, which remained in place due to the absence of a strong local bourgeoisie. Even if the peripheral insertion of backward societies within the international capitalist system posed unique challenges, the road to socialism passed through a successful and thorough transition to capitalism, which required accelerating industrial development. A different position was embraced by the so-called neo-populist school, which built on the $19^{\text {th }}$-century Russian Narodnik movement to analyze the distinctive features of peasant economies. Entering Romania mostly through the works of Alexander Chayanov, neo-populism sought to explain why the economic behavior of peasants differed in important respects from the standards prevailing in modern capitalist societies. It then used this knowledge to propose strategies for improving the lot of the peasantry, placing the agrarian sector at the heart of development policies.

\footnotetext{
${ }^{6}$ Programs and Census of Current Project, Russian Research Center, Harvard University, January 1949; NG-RP, Box 23, Folder 'Harvard University - Russian Research Center'.
} 
In the context of these disputes, Georgescu-Roegen decidedly took the side of the neopopulist cause. ${ }^{7}$ During his time at the Institute of Business Cycle Research, he worked closely with Virgil Madgearu, then chairman of the institute and secretary general of the Romanian National Peasant Party. A follower of Chayanov, Madgearu was the most prominent advocate of neo-populist ideas in Romania at the time (Love 1996, pp. 66-7). Late in his life, GeorgescuRoegen described Madgearu's book Agranianism, Capitalism, Imperialism (1936) as "a profound study worthy of being translated into English even, nay, especially today" (Georgescu-Roegen 1993, p. 5). He also claimed to have assisted Madgearu in completing his most well-known work, The Evolution of the Romanian Economy After the World War (1940). "My close collaboration with him," Georgescu-Roegen recalled, "taught me to appreciate the Peasantist program, and thinking that everyone must be a political soldier, I joined that Party, illegal though it had been since 1938". His wartime work also brought him in close contact with another distinguished Romanian economist, Mihail Manoïlescu. ${ }^{8}$ Regarded today as one of the pioneers of development economics, Manoïlescu popularized an argument for the industrialization of agrarian economies based on the different productivities of labor in industrial and agricultural activities (Love 1996, 82-4). The conflicting perspectives at play in interwar Romania - Marxism, neo-populism and

\footnotetext{
${ }^{7}$ Both Vivien (1999) and Bobulescu (2013) call attention to the influence of Chayanov and neopopulism on Georgescu-Roegen's bioeconomics, but without drawing connections to the history of development economics between the 1930s and 1960s.

${ }^{8}$ An active public figure in interwar Romania, Manoïlescu was an influential advocate for corporatist political ideology, who openly expressed his admiration for Fascist Italy and Nazi Germany during the 1930s (Love 1996, pp. 76-8, 94-8). He was appointed Minister of Foreign Affairs in 1940, in which capacity he led the Romanian mission when the infamous Vienna Diktat was negotiated, through which Germany and Italy imposed on Romania the cession to Hungary of the Northern half of Transylvania. Georgescu-Roegen participated in this diplomatic mission as part of the team of statisticians in charge of processing data from the Romanian population census (Georgescu-Roegen 1993, pp. 7-8).
} 
industrial protectionism - would serve as benchmarks for Georgescu-Roegen's own later forays into the study of economic development. ${ }^{9}$

At the Russian Research Center, Georgescu-Roegen was in contact with a diverse group of scholars, including Barrington Moore Jr., Alexander Gerschenkron, Alex Inkeles, Walter Galenson and Evsey Domar. Some of his colleagues encouraged him to enhance his study with more background information on the social practices related to land cultivation in Romania. $\mathrm{He}$ mentioned his intention to include the results of "some sociological investigations among peasants," bearing on issues such as "the type of work done by the peasant, the way the farm is run, $[\ldots]$ whether they use outside labor, whether members of the family work here or in other farms." ${ }^{10}$ Referring to the challenges surrounding the introduction of communism into a peasant society, he explained his desire to include a "special chapter" on mercantilism: "The new government preaches along these lines - speaks of Rumanian industry as not developed enough". Georgescu-Roegen's own attitude toward platforms of this type seems to have been colored in no small degree by his agrarian, neo-populist sympathies. Commenting on a draft of the first

\footnotetext{
${ }^{9}$ During the early stages of the research leading to his 1996 monograph, Joseph Love contacted Georgescu-Roegen asking for sources on interwar Romanian economic thought. In his reply, Georgescu-Roegen recommended the writings of Madgearu and the Marxist Lucretiu Patrascanu. He also suggested that Love should "point out the complete originality of Manoilescu's argument and, unfortunately, the stubborn opposition to it by Jacob Viner" (Letter from Joseph Love to Nicholas Georgescu-Roegen, February 26, 1981; Letter from Nicholas Georgescu-Roegen to Joseph Love, March 23, 1981; NG-RP, Box 28, Folder 'L 1964-1992'). In his later entry on Manoilescu to the New Palgrave, Georgescu-Roegen (1987) struck a similar positive (though restrained) note, recognizing the merits of Manoïlescu's analysis as a dynamic argument for industrialization. Curiously, when explaining the decision to exclude Georgescu-Roegen from consideration in his published study, Love (1996, p. 20, fn. 71) argued that "most of his research [...] did not deal with development issues".

${ }^{10}$ Minutes of the Meeting of the Economics Project Group, Russian Research Center, Harvard University, March 22, 1949; NG-RP, Box 23, Folder 'Harvard University - Russian Research Center'.
} 
chapters a few months later, Gerschenkron confessed to being "somewhat disturbed about the rather hostile remarks with respect to industrialization policies". ${ }^{11}$

Despite the vigorous start, however, Georgescu-Roegen's study of the Romanian economy never came to be published - in June 1949, he accepted an appointment as Professor of Economics at Vanderbilt University, thus effectively terminating his engagement with the Russian Research Center. At Vanderbilt, he took up lecturing duties on statistics and advanced economic theory, which caused him to leave aside for the moment his investigations on peasant economic organization. This temporary setback notwithstanding, the topic would be a constant fixture in his intellectual endeavors from then onward, cropping up on different occasions throughout the 1950s. In May 1954, he asked George Stocking, then chairman of Vanderbilt's Economics Department, for permission to dedicate his summer research to a project on the "economic history of the Rumanian peasantry," which he felt should have priority over his other commitments. By the end of the year, he claimed to be almost halfway through a book manuscript entitled A Political and Economic History of Rumania. ${ }^{12}$ The project never appeared in print, but the peculiar features of the Romanian economy served as inspiration for a paper he presented the following year at a symposium on linear programming organized by the United States Air Force.

The paper used the concept of limitative factors of production to discuss the existence of economic structures where marginal productivity theory did not work. The example GeorgescuRoegen chose to illustrate his argument was that of overpopulated agrarian countries, "particularly in the regions where capitalistic patterns have not yet fully penetrated" (GeorgescuRoegen 1966 [1955], p. 344). In such economies - "which in recent years," he said, "have become the object of increasing interest" - land functions as a limitative factor of production: given the large amount of available labor, an increase in land input is both a sufficient and a necessary condition for an increase in output. Under these circumstances, however, the marginal

${ }^{11}$ Letter from Alexander Gerschenkron to Nicholas Georgescu-Roegen, December 28, 1949; NGRP, Box 23, Folder 'Harvard University - Russian Research Center'.

${ }^{12}$ Letter from Nicholas Georgescu-Roegen to George Stocking, May 25, 1954; Letter from Nicholas Georgescu-Roegen to George Stocking, November 8, 1954; NG-RP, Box 26, Folder 'Vanderbilt-internal correspondence 1949-1960'. 
productivity of labor may not be enough to cover the basic subsistence costs of the laboring class. The failure of standard neoclassical analysis to determine an economically meaningful wage level thus meant that alternative distribution schemes would have to be devised. "One certainly would not expect a society that cannot live according to the Walrasian distribution theory," he argued, "to commit suicide rather than adopt another system." (p. 339)

Here the two topics that had mostly occupied Georgescu-Roegen's attention since returning to the United Stated coalesced: he used the tools of input-output analysis to develop an argument concerning the functioning of an overpopulated peasant economy, like that of his native country. The exercise led him to conclude there was something inherently distinct about such an economy, which made it sit uneasily with the standard assumptions of neoclassical theory, designed to account for the workings of a "land of plenty". In less developed countries, "social patterns differ from those of the more advanced communities," offering "other rules than the principle of maximizing profit" (p. 344). The argument was developed further in another paper, 'Economic Theory and Agrarian Economics', where Georgescu-Roegen sought to "point out the basic features that differentiate an overpopulated agricultural economy from an advanced economy" (Georgescu-Roegen 1960, pp. 1-2). He did so by emphasizing the cultural and institutional determinants behind all economic behavior, and then arguing that 'standard' economics had always been a theory of capitalist economies, characterized by capitalist institutions. Peasant economies, on the other hand, remained "a reality without a theory" (p. 4).

By thus focusing on the dual economic structure of overpopulated agrarian societies, Georgescu-Roegen invoked one of the touchstones of early development economics. The seminal contributions of Paul Rosenstein-Rodan $(1943,1944)$ and Kurt Mandelbaum (1945) grew out of studies of the problems of economic development in Eastern and Central Europe, pursued during World War II under the auspices of the Royal Institute of Economic Affairs (Alacevich 2018a). ${ }^{13}$ Such studies postulated a link between overpopulation and some form of disguised unemployment in the agricultural sector, and focused on strategies for incorporating the surplus agrarian population into economic activities with higher labor productivity, especially through industrialization - in the words of Rosenstein-Rodan (1943, p. 204), "to transform Eastern

\footnotetext{
${ }^{13}$ Rosenstein-Rodan, Mandelbaum, Michal Kalecki, and other economists working on this project were - like Georgescu-Roegen - emigrants from Eastern and Central Europe.
} 
European peasants into full-time or part-time industrial workers". A similar premise underlay the classic article of W. Arthur Lewis, which sought to adjust standard economic models to the case of economies where "an unlimited supply of labour is available at a subsistence wage," typically in the traditional agricultural sector (Lewis 1954, p. 189). Contrary to these pioneers of development economics, however, Georgescu-Roegen built on his neo-populist background to defend an approach that eschewed industrialization as a panacea to peasant societies.

'Economic Theory and Agrarian Economics' was originally published in a 1960 issue of Oxford Economic Papers, and it offers a typical illustration of Georgescu-Roegen's broadening intellectual concerns at the time. The paper's analytical core uses the toolbox of linear programming to examine the basic features of an overpopulated agrarian economy, but this exercise is nestled in a detailed discussion of the limitations of both neoclassical and Marxist theory when applied to such cases. After briefly discussing the cultural and institutional assumptions underlying both theoretical traditions, Georgescu-Roegen argued that "neither Marxist nor Standard theory is valid as a whole for the analysis of a non-capitalistic economy" (1960, p. 3). For one thing, there were important qualitative differences between the process of production in agriculture and industry - a point he would later develop at length in some of his most influential works (Georgescu-Roegen 1976 [1965], 1970, 1971). There was one intellectual tradition, however, which had examined the nature and problems of peasant economies in their own terms. Originally associated with the Narodnik movement, it found expression more recently in what Georgescu-Roegen termed Agrarianism, as exemplified by the works of Alexander Chayanov. ${ }^{14}$ Unfortunately, the Agrarians had "distinguished themselves by a lack of interest in, almost a spurn for, analytical preoccupations" (p. 10). ${ }^{15}$ Georgescu-Roegen thus purported to put their insights into a firmer theoretical basis, using the "familiar analytical tools of Standard theory" - the approach with which he still largely identified himself at this time.

\footnotetext{
${ }^{14}$ In a much later polemic on the pages of the Journal of Peasant Studies, Georgescu-Roegen (1981) reproached Utsa Patnaik for using the term 'neo-populism' instead of 'Agrarianism' to refer to the contributions of Chayanov and his followers.

${ }^{15}$ Georgescu-Roegen was later criticized by Daniel Thorner (1969) for severely underestimating the theoretical content of Chayanov's writings.
} 
To establish the premise that peasant economies were often plagued by overpopulation, thus leading to "the situation where the marginal productivity of labour equals zero," GeorgescuRoegen built on Doreen Warriner's groundbreaking study Economics of Peasant Farming (1939) and on the writings of his old colleague Virgil Madgearu. Reacting to a claim by Theodore Schultz (1956), to whom the hypothesis of zero marginal productivity found no supporting evidence in the agricultural activities of any poor country, he reasoned that overpopulation theories might not account for the developmental problems of Latin America - which mostly concerned Schultz - but not all underdeveloped economies were the same, and each should be assessed on its own grounds (1960, pp. 13-4). This was especially relevant if we hoped economic theory could help design and implement policies to assist the development of agrarian societies. "For an economic theory to be operational at all, to be capable of serving as a guide for policy," he argued, "it must concern itself with a specific type of economy, not with several types at the same time" (p. 2). The mere extrapolation of 'standard' theory would not do: "an intuitive knowledge of the basic cultural traits of a community is indispensable for laying out the basis of its economic theory" (p. 4). Conversely, this might lead to an enhanced understanding of the assumptions sustaining marginal productivity theory: "Very often, some features of a system become noticeable only under the light cast by a contrasting structure" (pp. 26-7).

Georgescu-Roegen chastised some of his fellow economists for advocating the use of marginal productivity analysis to judge investment priorities in less developed countries. "To assume that a process that sustains the progress of advanced economies necessarily befits an overpopulated economy is an unwarranted extrapolation," but the "ever-growing literature on economic development [...] abounds in such extrapolations" (p. 38). He mentioned papers by Alfred Kahn (1951) and Hollis Chenery (1953) as examples of this practice, adding that since "these criteria are endorsed by some economists serving as consultants to various economic development agencies, one may infer that they are used as a guide to public policy" (p. 39). The United Nations itself, he added, had endorsed the principle of marginal productivity in its report Measures for the Economic Development of Under-Developed Countries (1951). Contrary to this view, Georgescu-Roegen resorted once again to the neo-populist legacy: "Poor theorists though they have been, Agrarians have never lost sight of the most elementary principle of economic development, which is that no factor should remain unnecessarily idle" (p. 37). Decisions based strictly on profit maximization would lead to more unemployment and less wealth, since the 
marginal productivity of surplus labor was not enough to cover a subsistence wage. In this respect, "to regulate production by profit maximization is probably the worst thing that can happen to an overpopulated economy, for that would increase unwanted leisure while diminishing the national product" (p. 33).

The development strategy envisaged by Georgescu-Roegen did not involve the sudden introduction of capitalistic norms and practices, but a rational improvement of the feudalistic institutions that organized life in a peasant society. "Industrialize at all costs," he stated, "is not the word of economic wisdom, at least in overpopulated agricultural countries". Instead, one should rely on a "policy of radical agrarian reforms in overpopulated countries, by which the head of each peasant family is turned into a feudal entrepreneur" (pp. 34-5). This would ensure that productive factors were used to their full potential during the transition phase before the marginal productivity of labor finally rose above subsistence costs, and capitalist criteria could thus be adequately deployed. To Georgescu-Roegen, the path to this "advanced stage of economic development" necessarily involved a drastic temporary reduction of the leisure enjoyed by the working classes - what he termed, in a nod to Marx, the "growing pains of capitalism" ( $p$. 32). A tithe system applied to peasant agriculture could, in his view, foster this transition much more effectively than decisions based on profit maximization and marginal pricing.

Later in his life, Georgescu-Roegen recounted that a preliminary version of the idea contained in 'Economic Theory and Agrarian Economics' had been presented at an informal gathering at the University of Chicago in 1948. He often attributed the insight that marginal pricing was "the worst economic policy" in an overpopulated agrarian economy to his wartime experience working in Romania, when he found out that standard neoclassical theory was “violated by my own economic world" (Arestis \& Sawyer 2001, p. 222). The cold reception accorded to this idea at Chicago, however, led him to shelve the draft for an entire decade. When he finally decided to rescue it from oblivion, economic development had become a mainstream research topic. As he stated in the opening paragraphs, given the current state of international politics, "Standard economists have been almost compelled to come to grips with the problem of underdeveloped economies" (1960, p. 1). Nevertheless, they had failed to realize that such economies, being so removed from the values and institutions of Western capitalism, required their own special kind of theory. "The path followed by the West in its economic development," he concluded, "can help us in seeking a policy for the development of those areas that have 
remained behind. But it cannot show us the way" (p. 40). Recovering the insights of neopopulism, Georgescu-Roegen offered an alternative that challenged the widespread notion of industrialization as the surest escape from underdevelopment.

\section{Economic Development at Vanderbilt}

Georgescu-Roegen's affiliation to Vanderbilt University throughout the 1950s and 1960s did much to stimulate his involvement with the burgeoning field of development economics. In 1954, the university inaugurated a Summer Institute on Economic Development, a training program designed for students coming from less developed areas, which in 1956 morphed into the Graduate Program in Economic Development (GPED). The initiative built on the groundwork laid by Vanderbilt's Institute for Brazilian Studies, active between 1947 and 1953, and especially on the vision of Reynold Carlson, Georgescu-Roegen's friend and colleague, who had by then already accumulated a large experience working on aid missions to Latin America (Suprinyak \& Fernandez 2021). The program was initially funded by the International Cooperation Administration, and subsequently received generous grants from the Ford and Rockefeller foundations. Scholarships were awarded to students from different parts of the developing world - Southeast Asia, Latin America, Africa, and the Middle East - who would come to Vanderbilt to study for a Master's degree. Back in their home countries, most of them worked in some governmental agency in charge of economic administration and developmental planning, and the program sought to offer technical training that could be directly useful for their professional responsibilities. The GPED was thus a typical, albeit little noticed example of how the subject of economic development penetrated the economics profession during the 1950s, usually prompted by foreign aid agencies operating under a Cold War rationale. ${ }^{16}$

According to the GPED's first director, Rendigs Fels, the program was "based on the principle that economic theory is the same the world over but the institutional background and the policy problems of the developing countries are so different that it is a mistake to confine

\footnotetext{
${ }^{16}$ Scholarship on the history of development economics usually focuses on the much betterknown cases of the institutes created at Yale, Harvard, MIT, and Stanford to illustrate the academic institutionalization of the field during the 1950s (Alacevich 2018b, p. 126; Alacevich \& Boianovsky 2018, p. 4).
} 
foreign students to courses designed for Americans". ${ }^{17}$ The core curriculum comprised courses such as: Economic History and Economic Growth; Statistics for Economic Development; Foreign Trade Policy; Agriculture and Economic Development; Monetary and Fiscal Policies; Public Administration and Economic Development; Theories of Economic Growth; and Programming Economic Development. Moreover, the program gave much emphasis to a series of field trips around the Southern United States, in which students could acquire first-hand knowledge of initiatives designed to foster the development of some of the poorest areas of the country, including the works of the Tennessee Valley Authority. ${ }^{18}$

As a prominent member of Vanderbilt's modest-sized economics department, Georgescu-Roegen was inevitably involved with the program. After a visit to the university in 1957, Roger Evans, assistant director for the Social Sciences Division at the Rockefeller Foundation, wrote Georgescu-Roegen asking him to elaborate on the argument "made at luncheon for the development of economic theory appropriate to the different conditions and needs obtaining in underdeveloped countries". ${ }^{19}$ In his reply, Georgescu-Roegen argued that "western economists have continuously sworn by the Neo-Classical doctrine," while refusing to consider that this theory "is a description only of an economy which already has reached a certain degree of development so that the system of free enterprise could flourish in it". By extrapolating, he continued, "conclusions valid for a well-developed, free-enterprise economy to situations where neither production, nor consumption, nor human relations, are similar to those of capitalist countries, the economists of the West were bound to offer only unworkable recipes". This created suspicion within aid-recipient societies, whose leaders and elites grew estranged from Western ideology. To solve this problem - a crucial factor in the ongoing "East-West tug-of-war" Western economists needed to "recognize and learn the distinctive features of every

${ }^{17}$ Letter from Rendigs Fels to Robert Elmore, January 12, 1965; Vanderbilt University Archives, Box 693, Folder 32, 'USAID - Brazil'.

${ }^{18}$ Brochure for the Graduate Program in Economic Development; Vanderbilt University Archives, RG 300, Chancellor's Office, Box 162, Folder 5, 'Graduate Program of Economic Development (1954-62)'.

${ }^{19}$ Letter from Roger Evans to Nicholas Georgescu-Roegen, December 31, 1957; NG-RP, Box 25, Folder 'Rockefeller Foundation 1957-1976'. 
underdeveloped community," while "the growing generation of intellectuals in these communities should be helped to understand better the ethical superiority inherent in our own economic system," and "to know that an economic Jerusalem delivered overnight is not only a mirage, but a death-trap". ${ }^{20}$

Georgescu-Roegen believed that educational institutions could contribute to this purpose through their exchange programs with non-Communist, less developed societies. He took this message to Italy, where he spent the year 1958-59 lecturing on the "theoretical foundations of economic development" at the University Institute of European Studies in Turin, under a Fulbright scholarship. ${ }^{21}$ A much bigger opportunity to put this philosophy into practice, however, came a few years later. Having been awarded a Rockefeller Visiting Professorship to Japan during 1962-63, Georgescu-Roegen was sent on a mission to Southeast Asia on behalf of the GPED, during the spring of 1962, to establish contact with US aid missions and recruit students for the program..$^{22}$ Between February and May, he visited the Philippines, Indonesia, Vietnam, Singapore, Malaya, Hong Kong, Thailand, and Taiwan - after settling in Japan, he also took a short trip to South Korea. By then, Vanderbilt's GPED already had several alumni in most of these countries, which enabled Georgescu-Roegen to rely on local networks to access the elite circles of government administration, development planning and university education. He also came in close contact with the field work being done by USAID missions in the area, sometimes with the collaboration of other US educational institutions. ${ }^{23}$

${ }^{20}$ Letter from Nicholas Georgescu-Roegen to Roger Evans, January 3, 1958; NG-RP, Box 25, Folder 'Rockefeller Foundation 1957-1976'.

${ }^{21}$ Letter from Saxton Bradford to Harvie Branscomb, October 21, 1959; NG-RP, Box 22, Folder 'Guggenheim + Fulbright Foundations 1957-9'.

${ }^{22}$ Letter from Anthony Tang to Nicholas Georgescu-Roegen, January 23, 1962; NG-RP, Box 20, Folder '1962-3; Agency for International Development'.

${ }^{23}$ Georgescu-Roegen quickly realized that when a university operated a field mission in an aidrecipient country, it stood to benefit greatly from the opportunities created by US assistance. This was the case, for instance, of Michigan State University's involvement with Vietnam. Report on Saigon, undated (c. Feb. 1962); NG-RP, Box 20, Folder '1962-3; Agency for International Development'. 
Georgescu-Roegen's travel reports make for a rich ethnographic record, written by someone who, not unfamiliar with the realities of life outside the Western developed world, could grasp the diversity of social experiences hidden behind the common label of 'underdevelopment'. From Indonesia, he departed with "a feeling of despair," convinced that "no one can have a complete idea of the problems raised by a truly underdeveloped economy" before witnessing the situation prevailing in that country. Indonesian people, nevertheless, were "usually goodhumored and hard-working". In such a situation, he argued, "the education of the 'educated' is a far more urgent task than any economic planning," but this long-term strategy ran against widespread social impatience, "rendered even more so by many of us who maintain that a simple economic formula will bring the New Jerusalem within a fortnight". ${ }^{24}$ After visiting Bangkok, he felt "the Thai people seem to lack any sense of public administration," while being "rather overconfident in their ability to handle their internal and external affairs". He was shocked by the protocols of royalty surrounding public administration, which included "servants moving around on their knees while serving drinks or bringing in dishes". This relic from the past could only survive, in his opinion, due to the relatively favorable economic conditions prevailing in Thailand, a country "not plagued by overpopulation" and never "exploited by a colonial power". ${ }^{25}$

Even if Georgescu-Roegen thought he "knew pretty well the limit of economic misery" from his experiences in Eastern Europe, he came to realize that nothing could "compare with the conditions in which most Chinese live in Hong Kong," where entire families lived "on a sort of large bed", taking shifts to sleep during the day or at night. "It is striking," he added, "that in spite of these inhuman conditions, the poor do not show any sign of despair: they work hard and with a visible intention of doing well what they are supposed to do". Taiwan, in contrast, offered a much more hopeful picture: there was no misery, and "even the poorest people in towns or villages look well fed, cleanly dressed, continuously busy and efficiently so". The Taiwanese agricultural sector "invites only praise," and Georgescu-Roegen claimed he had never seen "such

\footnotetext{
${ }^{24}$ Letter from Nicholas Georgescu-Roegen to Anthony Tang, February 28, 1962; NG-RP, Box 20, Folder '1962-3; Agency for International Development'.

${ }^{25}$ Report on Bangkok, undated (c. Feb. 1962); NG-RP, Box 20, Folder '1962-3; Agency for International Development'.
} 
absolutely clean railway stations". ${ }^{26}$ Malaya also seemed to fare well in economic terms, apart from the danger inherent in the "racial conflict between the Malay and the Chinese". After visiting the University of Malaya's new campus, Georgescu-Roegen said he wished "Vanderbilt could be 'underdeveloped' to the same level". ${ }^{27}$ In Saigon, however, the grim reality of economic and social destitution was overwhelming: he claimed to have left the city "deeply disturbed," seeing Vietnam as "a most unhappy nation with little hope of being helped out, a most glaring symptom of a troubled and sick world". 28

During his tour of Southeast Asia, Georgescu-Roegen lectured at institutions such as the Institute of Economic Development in the Philippines, the Joint Commission on Rural Reconstruction in Taiwan, and the Korean Bank of Reconstruction, besides several local universities. His lecture topics included 'Economic Development in Agricultural Countries' and 'Why One May Become Disappointed in Mathematical Economics'. He also acquired first-hand knowledge of some of the operational difficulties associated with the work of development aid missions. From his conversations with one of his local contacts in Kuala Lumpur, GeorgescuRoegen came to appreciate the hostility that existed in Malaya toward foreign experts working in the country. The attitude was understandable, since "some of these experts take on an air of superiority as if they would be running the country". His interaction with the Economic Advisor to the Malayan Prime Minister, an economist from Johns Hopkins "who did not condescend to address me a single word" during a three-hour field trip, made him even more sympathetic to these complaints. ${ }^{29}$ A similar experience took place in South Korea, where he was "surprised to hear several of our officials scorn at the idea of Korea having an economic plan or computing an input-output table". Even if these tasks were, for the moment, beyond the capacity of local

${ }^{26}$ Report on Hong Kong and Taiwan, undated (c. Feb. 1962); NG-RP, Box 20, Folder '1962-3; Agency for International Development'.

${ }^{27}$ Report on Singapore and Kuala Lumpur, undated (c. Feb. 1962); NG-RP, Box 20, Folder '1962-3; Agency for International Development'.

${ }^{28}$ Report on Saigon, undated (c. Feb. 1962); NG-RP, Box 20, Folder '1962-3; Agency for International Development'.

${ }^{29}$ Report on Singapore and Kuala Lumpur, undated (c. Feb. 1962); NG-RP, Box 20, Folder '1962-3; Agency for International Development'. 
administrators, striving in earnest to achieve them was the only path to progress. GeorgescuRoegen concluded that "such experts completely lack the understanding necessary" for their work in less developed areas. "An ultra-inflated superiority complex," he added, "causes them to find fault with an underdeveloped nation no matter what the latter would try to do. No wonder, then, that in most cases the American Advisor is welcomed on the surface - because he usually brings some financial aid as well - but is highly disliked au fond" ${ }^{30}$

In Japan, Georgescu-Roegen lectured in Osaka and Tokyo, covering topics such as 'The Economic Lessons of Japan's Economic Development' and 'Economic Development Made Simple'. ${ }^{31}$ After leaving Japan, he spent the early months of 1963 in India, where he met colleagues such as Paul Streeten, Edward Mason and John Kenneth Galbraith. ${ }^{32}$ To Rendigs Fels, then chairman of Vanderbilt's Economics Department, he stressed his "special interest in the problem of economic development in overpopulated economies," and his belief that India constituted "the most interesting case study for this problem". ${ }^{33}$ Besides lecturing in New Delhi, he hoped to "meet the local economists and learn from them something about their economic planning". After suffering with "heat, stomach troubles, and the ghastly sight of human misery," Georgescu-Roegen felt he had come to "realize how really formidable can be the task of developing a backward economy". ${ }^{34}$ India served as the launching pad for a new mission on behalf of Vanderbilt's GPED, this time to the Middle East: April and May included visits to Pakistan, Iran, Jordan, Lebanon, Egypt, and Turkey. While in Iran, he received a letter from Fels acknowledging his interest in teaching Economic Development, and stating he would be a perfect

\footnotetext{
${ }^{30}$ Letter from Nicholas Georgescu-Roegen to Anthony Tang, October 14, 1962; NG-RP, Box 20, Folder '1962-3; Agency for International Development'.

${ }^{31}$ Letter from Nicholas Georgescu-Roegen to Reynold Carlson, June 5, 1964; NG-RP, Box 15, Folder '1964; University of São Paolo visit, via Ford Foundation'.

32 Letter from Nicholas Georgescu-Roegen to Rendigs Fels, March 17, 1963; NG-RP, Box 22, Folder 'Fels, Rendigs 1962-3'.

${ }^{33}$ Letter from Nicholas Georgescu-Roegen to Rendigs Fels, December 5, 1962; NG-RP, Box 22, Folder 'Fels, Rendigs 1962-3'.

${ }^{34}$ Letter from Nicholas Georgescu-Roegen to Reynold Carlson, March 17, 1963; NG-RP, Box 20, Folder '1962-3; Agency for International Development'.
} 
fit for a course on 'Programming Economic Development'. ${ }^{35}$ Back in Nashville in October, Georgescu-Roegen told Clifton Wharton, an economist who worked for the Rockefeller Foundation's Agricultural Development Council in Malaya, that his recent tour of the Middle East, "combined with the result of my stay in Japan and my visit to South East Asia in the spring of 1962, opened for me new horizons of theoretical inquiries, which I hope to accomplish within the near future". 36

\section{From Economic Development to Bioeconomics}

For an admirer of Georgescu-Roegen's bioeconomic approach, the years between 1965 and 1971 might very well seem to be the apex of his intellectual career, culminating with the publication of The Entropy Law and the Economic Process (1971). Significantly, though, his well-known achievements from this period overlap a great deal with Georgescu-Roegen's continuing inquiries into the problems of economic development. After Southeast Asia and the Middle East, his involvement with Vanderbilt's GPED brought him to yet another less developed region: Latin America. Between 1964 and 1973, he visited Brazil on multiple occasions, getting acquainted with local problems and establishing strong personal connections with part of the community of Brazilian economists. While he worked on some of his groundbreaking contributions to economic theory, Georgescu-Roegen was thus simultaneously involved in an educational exchange program designed to bring useful technical and scientific knowledge to a (non-Communist) less developed society.

After returning from his first visit to Brazil in 1964, Georgescu-Roegen received two invitations to participate in academic events the following year. One of them came from Clifton Wharton, who was organizing a conference on Subsistence and Peasant Economics, "seriously to analyze the behavior of peasant farmers with respect to production and consumption and to assess the extent to which 'economic' decisions of farmers are made on the basis of considerations other

\footnotetext{
${ }^{35}$ Letter from Rendigs Fels to Nicholas Georgescu-Roegen, March 28, 1963; NG-RP, Box 22, Folder 'Fels, Rendigs 1962-3'.

${ }^{36}$ Letter from Nicholas Georgescu-Roegen to Clifton Wharton, October 22, 1963; NG-RP, Box 20, Folder 'Agricultural Development Council (Subsistence and Peasant Economics)'.
} 
than market prices". ${ }^{37}$ This played right into the topics Georgescu-Roegen had explored in 'Economic Theory and Agrarian Economics' and he promptly accepted the invitation, preparing a manuscript entitled 'The Institutional Aspects of Peasant Economies: An Historical and Analytical Review'. ${ }^{38}$ Once again, he pitched the Narodnik-Agrarian tradition against both Marxian and neoclassical economics, situating it at the origins of a "peasant sociology" (1976 [1969], p. 202) ${ }^{39}$ With a new emphasis on the biological underpinnings of economic development, he voiced concern with the pressure exerted by growing population over natural resources, which risked leading less developed societies into a Malthusian trap. Pointing to Ragnar Nurkse's Problems of Capital Formation in Underdeveloped Countries (1953) as an example, Georgescu-Roegen criticized the "idea of absorbing the agricultural labor surplus through industrialization and of concomitantly preventing those remaining on the land from increasing their average consumption of food," a policy resting on "an old idea that the peasant is only a special kind of draft animal entitled to a subsistence ration of food and nothing else" ( $p$. 228). Contrariwise, economic sacrifices had to come from the urban sector, so that the countryside could expand its productive capacity and provide a more solid base for future development.

${ }^{37}$ Letter from Clifton Wharton to Nicholas Georgescu-Roegen, June 22, 1964; NG-RP, Box 20, Folder 'Agricultural Development Council (Subsistence and Peasant Economics)'. ${ }^{38}$ In a letter thanking Georgescu-Roegen for a copy of Energy and Economic Myths, Douglass North reported: "I have read and reread your essays on 'Peasant Economies' and they are exerting a substantial influence on my thinking about other forms of economic organization than market systems and exclusive property rights". (Letter from Douglass North to Nicholas Georgescu-Roegen, December 7, 1976; NG-RP, Box 29, Folder 'Fan Mail 1977-8'. ${ }^{39}$ During the preparation of the volume where this paper originally appeared, Clifton Wharton told Georgescu-Roegen he had edited his manuscript "to reduce the content devoted to the ideological battles of the past (Narodniki, Agrarians, et al)". One may thus reasonably assume this discussion featured even more prominently in early drafts. (Letter from Clifton Wharton to Nicholas Georgescu-Roegen, February 12, 1968; NG-RP, Box 20, Folder 'Agricultural Development Council (Subsistence and Peasant Economies)'. 
The second invitation referred to the 1965 Rome Conference of the International Economic Association, dedicated to the topic 'Economic Problems of Agriculture in Industrial Societies and Repercussions in Developing Countries'. The organizers asked Georgescu-Roegen to prepare a paper on 'The Place of Agriculture in a Process of Balanced Growth', leading to the first draft of 'Process in Farming versus Process in Manufacture'. Expanding on another topic already sketched in his 1960 paper, he proposed to show "the analytical differences between the process pertaining to agricultural produce and that pertaining to manufacture," and "the implication of this difference regarding general development". ${ }^{40}$ Using his flow-fund approach to criticize neoclassical representations of the production function, Georgescu-Roegen showed how the latter distorted the analysis of agricultural activities, which were not amenable to the continuous operation typical of the factory process. As a result, "agricultural production inevitably imposes some idleness on both capital and labour over the production period" (1976 [1965], p. 99). Prescribing a recipe for balanced economic development, he once again stressed that it was "the turn of the town now to support the economy of the countryside," producing the fertilizers and machinery necessary to increase agricultural productivity - even if this came at the price of reduced urban leisure and consumption.

During his stay in Japan, Georgescu-Roegen had already begun to work on some of the themes that would later appear in the long introductory essay to Analytical Economics, which clearly signaled his move toward the research agenda of bioeconomics. The core of his seminar lectures at Osaka and Hitotsubashi was mimeographed and circulated with the title 'Process, Value, and Development', where we find embryonic discussions on the relevance of dialectical concepts in economics and the entropic nature of the economic process. ${ }^{41}$ 'Process, Value, and Development' was also the title of a research project he submitted to the National Science

${ }^{40}$ Letter from G.U. Papi to Nicholas Georgescu-Roegen, July 24, 1964; Letter from Nicholas Georgescu-Roegen to G.U. Papi, September 15, 1964; NG-RP, Box 23, Folder 'International Economic Association 1965-9'.

${ }^{41}$ Process, Value, and Development; NG-RP, Box 4, Folder 'Process, Value, Development. Draft, 1963'. The same material was also elaborated, apparently around the same time, in a manuscript entitled 'Logical and Empirical Foundations of Economic Development' (NG-RP, Box 3, Folder 'Logical + Empirical Foundations of Economic Development, Draft'). 
Foundation in 1967, pointing to the subjects later elaborated in The Entropy Law and the Economic Process. After describing his general approach and the results obtained so far, Georgescu-Roegen concluded: "In the ultimate analysis, my interest lies in problems and, especially, policy recommendations pertaining to economic development". ${ }^{42}$ The project was alternatively titled 'Studies in the Theory of Economic Development', and served as an umbrella for Georgescu-Roegen's scholarly endeavors during the years 1967-71, building on the notion that "traditional, nonmarket, and especially agricultural societies present specific problems that cannot be formulated within the neoclassical economic framework". ${ }^{43}$

The preparation of Analytical Economics (1966) gave him an occasion to elaborate some of the arguments on economic development he had been maturing for some time. After giving the first thorough exposition of his thesis on the importance of dialectical reasoning for the scientific understanding of evolution and change, Georgescu-Roegen argued it was only natural that 'standard' economists would have patterned their models after capitalist societies. "The egregious sin of the standard economist," he added, "is of another kind. Because he denies the necessity of paying any attention to the evolutionary aspects of the economic process, he is perforce obliged to preach and practice the dogma that his theory is valid in all societies" (1966, pp. 110-1). This wrong-headed extrapolation was not merely an academic affair, having "farreaching consequences for the world's efforts to develop the economy of nations which differ in their institutions from the capitalist countries". The results of such efforts, therefore, "may go down in history as the greatest monument to the arrogant self-assurance of some of science's servants" (pp. 113-4). To illustrate his point, Georgescu-Roegen returned to a subject he had already briefly addressed in 'Economic Theory and Agrarian Economics':

$[\mathrm{M}]$ ost of us now swear by the axiom - which actually goes back to Marx - that industrial development is the only road to general economic development, that is, to the development of the agricultural sector as well. As factual evidence we invoke the incontrovertible fact that industrialization did result in the over-all development of the

\footnotetext{
${ }^{42}$ Process, Value, and Development: A Research Proposal Submitted to National Science Foundation; NG-RP, Box 24, Folder 'National Science Foundation 1967-71, 73-82'.

${ }^{43}$ Project Summary, Studies in the Theory of Economic Development, December 12, 1967; NGRP, Box 24, Folder 'National Science Foundation 1967-71, 73-82'.
} 
South of the United States. But the ingrained outlook of the standard economist prevents us from noting first, that the South is part and parcel of the most advanced capitalist economy, and second, that the American farmer is not institutionally identical (or even comparable) to the Indian or any other peasant. In fact, the greater the industrial development achieved by an underdeveloped nation plagued by a predominant, over-populated, and disorganized agricultural sector, the stronger the evidence such a nation offers of the fallacy of the industrialization axiom. There the peasantry is still as poverty-stricken as ever - a passive gloomy onlooker at the increasing well-being of the exclusive circle that delights in the Square Dance of Effective Demand, which alone moves faster and faster with each day (GeorgescuRoegen 1966, p. 114)

Georgescu-Roegen thus claimed for the replacement of "mathematical macro-models" with less ambitious, more down-to-earth analyses of the problems of economic development, citing his long-time friend Simon Kuznets as a leading example in this regard (1966, p. 123). ${ }^{44}$ He remarked on the perplexity of 'standard' economists when facing the protestations of scholars from the German historicist tradition who wished to incorporate "such 'obscurantist' ideas as Geist or Weltanschauung into the economic science," but concluded that "the much better faring of standard economics notwithstanding, it is the position of the historical school that is fundamentally the correct one" (p. 124). The tenets of rational behavior postulated by standard economics represented the rationality of a modern, capitalist society, and the "voluntary midwives" of economic development failed to realize "the inertia any tradition has because of the superb internal logic of many of its articulations" (p. 126). Georgescu-Roegen cited Leonard Doob and Joseph Spengler as examples of "unorthodox" economists who recognized the importance of "cultural propensities" and "local mores" for the design of effective foreign aid

\footnotetext{
${ }^{44}$ After Kuznets won the Nobel Prize in 1971, Georgescu-Roegen wrote him a letter of congratulations stressing how much he had praised his work in both Analytical Economics and the recently-published The Entropy Law and the Economic Process. He claimed to have "felt so happy that your approach and your method was finally recognized in a epoch full of complex yet empty mathematical models" (Letter from Nicholas Georgescu-Roegen to Simon Kuznets, November 29, 1971; NG-RP, Box 23, Folder 'Kuznets, Simon 1971').
} 
policies, while regretting that "most policies of economic development still rest on the old fallacy bred by the mechanistic philosophy, the fallacy that it is the machines that develop man, not man that develops machines" (pp. 127-8, emphasis in the original).

After the manuscript of Analytical Economics had been finished, Georgescu-Roegen returned to Brazil in 1966 as part of the recently-signed agreement between Vanderbilt and the University of São Paulo (Suprinyak \& Fernandez 2018). Upon gaining some first-hand knowledge of the inflationary problems confronting the Brazilian economy, he offered a theoretical treatment of the subject in 'Structural Inflation-Lock and Balanced Growth', showing how "prolonged inflation in a country with a strong inheritance of 'feudalistic' social and economic" institutions tended to produce an industrial structure that can only be sustained by "an artificial maintenance of the effective demand for 'superior', i.e., luxury, consumer goods". ${ }^{45}$ Once again, he built on his long-standing interest in dual economic structures to explore how certain institutional patterns found in less developed societies constrained their capacity to generate a self-sustaining process of economic growth. ${ }^{46}$ Georgescu-Roegen understood this contribution as part of his larger project at the time, an illustration of the irreversible nature of investment decisions - a "kind of physiological analysis of inflation applied to Latin American countries" (Georgescu-Roegen 1976, p. xx). ${ }^{47}$ In line with his earlier writings, he criticized the industrialization policies pursued in Brazil for aggravating a pattern of income and wealth distribution that only benefited the upper strata of society, leaving the poor to bear the burden of inflation (Georgescu-Roegen 1976 [1970]).

With the publication of The Entropy Law and the Economic Process, GeorgescuRoegen's interests took a decisive turn toward the subject of natural resource allocation and the relationship between economic and biological processes. By then, however, his reputation as a development economist was already firmly established. In 1972, he was invited by the Director

\footnotetext{
${ }^{45}$ Report on the Research Project GS-1801, 'Studies in the Theory of Economic Development'; NG-RP, Box 24, Folder 'National Science Foundation 1967-71, 73-82'.

${ }^{46}$ For a discussion of how Georgescu-Roegen's paper interacted with ongoing theoretical and policy debates in Brazil, see Carvalho \& Suprinyak (2019).

${ }^{47}$ Letter from Nicholas Georgescu-Roegen to Robert Lagemann, December 5, 1967; NG-RP, Box 26, Folder 'Vanderbilt-internal correspondence 1961-71'.
} 
of the World Bank's Economic Development Institute to lecture on the major themes of his recent book to the institute's staff, dedicated to "training middle- and senior-grade civil servants from the developing countries". ${ }^{48}$ The Brazilian National Bank for Economic Development had sent him a similar invitation a few months earlier, asking him to participate in its upcoming $20^{\text {th }}$ anniversary celebrations delivering a paper that could offer "a valuable contribution in terms of policy-making guidelines in the nation's current near-take-off-point, stepped up development phase". ${ }^{49}$ Georgescu-Roegen accepted to join the event with a contribution titled 'The Physiology of Economic Development', and began to prepare for yet another tour of Brazil. ${ }^{50}$ Prior to his trip, however, he still enjoyed the opportunity of participating in an NBER conference on the topic 'New Directions in Federal Economic Development Programs'.51

Throughout this entire period, the coherence for his forays into development economics came from his concern with the institutional specificities of peasant societies. Still in the early 1970s, he kept working on a book project entitled 'Peasant Economy: An Analytical and Historical Study'. ${ }^{52}$ Even though the volume never came to fruition, Georgescu-Roegen's expertise on the subject was widely recognized. In 1972, he joined a mission to Ghana sponsored by the Canadian International Development Agency, "to help the economic agencies of the country plan for agrarian reform". ${ }^{53}$ Shortly thereafter, "Economic Theory and Agrarian Economics' was once again reprinted as part of the volume Essays on Coffee and Economic

${ }^{48}$ Letter from Andrew Karmack to Nicholas Georgescu-Roegen, August 29, 1972; NG-RP, Box 23, Folder 'International Bank for Reconstruction and Development 1972-3'. ${ }^{49}$ Letter from the João Paulo dos Reis Velloso et alli to Nicholas Georgescu-Roegen, June 6, 1972; NG-RP, Box 20, Folder '1972-1973; Banco Nacional do Desenvolvimento Econômico'. ${ }^{50}$ Letter from Nicholas Georgescu-Roegen to João Paulo dos Reis Velloso, August 2, 1972; NGRP, Box 20, Folder '1972-1973; Banco Nacional do Desenvolvimento Econômico'.

${ }^{51}$ Letter from Edward Smith to Nicholas Georgescu-Roegen, January 2, 1973; NG-RP, Box 24, Folder 'National Bureau of Economic Research 1973-4'.

52 Project Description, 'Peasant Economy: An Analytical and Historical Study'; NG-RP, Box 26, Folder 'Vanderbilt-internal correspondence 1961-71'.

${ }^{53}$ Press Release, Vanderbilt University, March 1972; NG-RP, Box 26, Folder 'Vanderbiltinternal correspondence 1961-71'. 
Development, edited by the Brazilian Coffee Institute. By now, it was already billed as a "classic contribution". ${ }^{44}$ The journey came full circle in 1974, when Georgescu-Roegen was invited by his old friends Samuelson and Leontief to return to Harvard, his adopted alma mater, and lecture on "a subject which would be of great interest to both faculty and students:" development planning. ${ }^{55}$

\section{Concluding Remarks}

Late in his life, Nicholas Georgescu-Roegen sought to distance himself from the type of scholarly inquiry associated with development economics. This undoubtedly had to do with his growing estrangement from the mainstream of the economics profession, on one hand, and his distaste for what he saw as a wrong-headed emphasis on capital accumulation and GDP growth as goals of developmental policy, on the other. He grew weary of the "self-confidence of planners" who did not take proper notice of the institutional underpinnings of economic life. ${ }^{56}$ Invited to Brazil one last time in 1978, he no longer wished to talk about economic development, choosing instead to focus on topics related to natural resources and energy-saving technology. ${ }^{57}$ Such rebelliousness should cause little surprise coming from someone who had learned to revel on the thought of being a dissenting voice. Neither should it obscure, however, the depth and consistency of Georgescu-Roegen's involvement with the problems of economic development throughout the most productive phase of his career. Economic development was neither an interlude, nor a side note to his other ventures, but rather the opposite: it structured his scholarly engagements and provided some coherence of purpose to his manifold projects. From his experiences during the $1960 \mathrm{~s}$, he acquired a profound sense of the different values and

\footnotetext{
${ }^{54}$ Letter from Mauro Malta to Nicholas Georgescu-Roegen, January 10, 1973; NG-RP, Box 28, Folder 'M 1955-93'.

${ }^{55}$ Letter from Wassily Leontief to Nicholas Georgescu-Roegen, October 7, 1974; NG-RP, Box 23, Folder 'Leontief, Wassily 1948-49, 64-74'.

${ }^{56}$ Letter from Nicholas Georgescu-Roegen to Wolfgang Stolper, February 12, 1971; NG-RP, Box 28, Folder 'Fan Mail 1971-4 Re: The Entropy Law and the Economic Process'. ${ }^{57}$ Letter from Nicholas Georgescu-Roegen to Aristides Leão, April 19, 1978; NG-RP, Box 17, Folder '1978; Trip to Brazil'.
} 
institutions that sustained life in less developed societies, a perception that resurfaced in his later work on bioeconomics when he contrasted, for instance, the habits and behavior of Homo Indicus and Homo Americanus (Georgescu-Roegen 1978). As he confessed in a letter to Stefano Zamagni, "it was the problem of agricultural economics (understood in a different way than farming business) that led me to many other 'irritating' ideas". 58

Apart from his own intellectual struggles, Georgescu-Roegen's case also illustrates, on one hand, the widespread concern with economic development that took hold of the economics profession during the 1950s and 1960s, and on the other, the different avenues open for inquiry on the subject. In those days, development economics was an open-ended enterprise, ranging from field missions to high theory, from programming techniques to ethnographic speculation. Georgescu-Roegen did a little of it all, and yet retained a unique perspective that set him apart from the mainstream in the field. Like his contemporary Dudley Seers (1963), he questioned both neoclassical and Marxian approaches to the problems of underdevelopment, but his own vision was grounded on a different tradition descended directly from the neo-populist ideas of Chayanov, Madgearu and others who examined the economic plight of interwar Romania. If their influence made Georgescu-Roegen appear quaint and out-of-touch when industrialization policies ruled the day, they also led to his partial rescue once neo-populism regained currency, more recently, as an alternative platform of economic development. ${ }^{59}$

\section{REFERENCES}

Alacevich, Michele. 2018a. "Planning Peace: The European Roots of the Post-War Global Development Challenge." Past and Present 239 (1): 219-264.

Alacevich, Michele. 2018b. "The Birth of Development Economics: Theories and Institutions." History of Political Economy 50(Annual Supplement): 114-132.

${ }^{58}$ Letter from Nicholas Georgescu-Roegen to Stefano Zamagni, November 6, 1981; NG-RP, Box 27, Folder 'Zamagni, Stefano 1976-86, 1991'

${ }^{59}$ For recent works that enlist both Chayanov and Georgescu-Roegen as sources of inspiration for a new paradigm of economic development, see Martinez-Alier (1997), Sivakumar (2010) and Gerber (2020). 
Alacevich, Michele \& Boianovsky, Mauro. 2018. "Writing the History of Development Economics." History of Political Economy 50 (Annual Supplement): 1-14.

Arestis, Phillip \& Sawyer, Malcolm. 2001. A Biographical Dictionary of Dissenting Economists Second Edition. Cheltenham, UK, \& Norhtampton, USA: Edward Elgar.

Bobulescu, Roxana. 2012. "The Making of a Schumpeterian Economist: Nicholas GeorgescuRoegen." The European Journal of the History of Economic Thought 19 (4): 625-651.

Bobulescu, Roxana. 2013. “L’expérience roumaine et son influence sur la pensée de Nicholas Georgescu-Roegen.” Économies et Sociétés 47 (10): 1731-1752.

Carvalho, André R. \& Suprinyak, Carlos E. 2019. “An Emigrant Economist in the Tropics: Nicholas Georgescu-Roegen on Brazilian Inflation and Development." Cedeplar Working Paper no. 604, Belo Horizonte.

Chenery, Hollis B. 1953. "The Application of Investment Criteria.” The Quarterly Journal of Economics 67 (1): 76-96.

Düppe, Till \& Weintraub, E. Roy. 2014. "Siting the New Economic Science: The Cowles Commission's Activity Analysis Conference of June 1949." Science in Context 27 (3): $453-$ 483.

Georgescu-Roegen, Nicholas. 1950. "Leontief's System in the Light of Recent Results." The Review of Economics and Statistics 32 (3): 214-222.

Georgescu-Roegen, Nicholas. 1951a. "Relaxation Phenomena in Linear Dynamic Models.” In Tjalling Koopmans, ed., Activity Analysis of Production and Allocation. New York: John Wiley and Sons, pp. 116-31.

Georgescu-Roegen, Nicholas. 1951b. “Some Properties of a Generalized Leontief Model.” In Tjalling Koopmans, ed., Activity Analysis of Production and Allocation. New York: John Wiley and Sons, pp. 165-173.

Georgescu-Roegen, Nicholas. 1966 [1955]. “Limitationality, Limitativeness and Economic Equilibrium.” In Nicholas Georgescu-Roegen, Analytical Economics: Issues and Problems. Cambridge, Mass.: Harvard University Press, pp. 338-355. 
Georgescu-Roegen, Nicholas. 1960. "Economic Theory and Agrarian Economics." Oxford Economic Papers 12 (1): 1-40.

Georgescu-Roegen, Nicholas. 1966. Analytical Economics: Issues and Problems. Cambridge, Mass.: Harvard University Press.

Georgescu-Roegen, Nicholas. 1970. "The Economics of Production.” The American Economic Review 60 (2): 1-9.

Georgescu-Roegen, Nicholas. 1971. The Entropy Law and the Economic Process. Cambridge, Mass.: Harvard University Press.

Georgescu-Roegen, Nicholas. 1976. Energy and Economic Myths: Institutional and Analytical Economic Essays. New York: Pergamon Press.

Georgescu-Roegen, Nicholas. 1976 [1965]. "Process in Farming versus Process in Manufacturing: A Problem of Balanced Development.” In Nicholas Georgescu-Roegen, Energy and Economic Myths. New York: Pergamon Press, pp. 71-102.

Georgescu-Roegen, Nicholas. 1976 [1969]. "The Institutional Aspects of Peasant Communities: An Analytical View." In Nicholas Georgescu-Roegen, Energy and Economic Myths. New York: Pergamon Press, pp. 199-231.

Georgescu-Roegen, Nicholas. 1976 [1970]. "Structural Inflation-Lock and Balanced Growth.” In Nicholas Georgescu-Roegen, Energy and Economic Myths. New York: Pergamon Press, pp. 149-197.

Georgescu-Roegen, Nicholas. 1978. "De la science économique à la bioéconomie.” Revue d'Économie Politique 88 (3): 337-382.

Georgescu-Roegen, Nicholas. 1981. “On Neo-Populism and Marxism: A Comment on Utsa Patnaik." The Journal of Peasant Studies 8 (2): 242-243.

Georgescu-Roegen, Nicholas. 1988. “An Emigrant from a Developing Country: Autobiographical Notes.” Banca Nazionale del Lavoro Quarterly Review 41 (164): 3-31.

Georgescu-Roegen, Nicholas. 1992. "Nicholas Georgescu-Roegen about Himself." In Michael Szenberg, ed., Eminent Economists: Their Life Philosophies. Cambridge, UK: Cambridge University Press, pp. 128-59. 
Georgescu-Roegen, Nicholas. 1993. "An Emigrant from a Developing Country:

Autobiographical Notes II." Banca Nazionale del Lavoro Quarterly Review 46 (184): 3-30.

Georgescu-Roegen, Nicholas. 1997. "Manoïlescu, Mihail (1891-?1950).” In Steven Durlauf and Lawrence Blume, eds., The New Palgrave Dictionary of Economics, $2^{\text {nd }}$ edition. London: Palgrave Macmillan.

Gerber, Julien-François. 2020. "Degrowth and Critical Agrarian Studies." The Journal of Peasant Studies 47 (2): 235-264.

Gowdy, John \& Mesner, Susan. 1998. "The Evolution of Georgescu-Roegen's Bioeconomics.” Review of Social Economy 56 (2): 136-156.

Kahn, Alfred E. 1951. "Investment Criteria in Development Programs," The Quarterly Journal of Economics 65 (1): 38-61.

Lewis, W. Arthur. 1954. "Economic Development with Unlimited Supplies of Labour." The Manchester School 22 (2): 139-191.

Love, Joseph L. 1996. Crafting the Third World: Theorizing Underdevelopment in Rumania and Brazil. Stanford, CA: Stanford University Press.

Mandelbaum, Kurt. 1945. The Industrialisation of Backward Areas. Oxford: Basil Blackwell.

Maneschi, Andrea \& Zamagni, Stefano. 1997. "Nicholas Georgescu-Roegen, 1906-1994.” The Economic Journal 107 (442): 695-707.

Martinez-Alier, Joan. 1997. "Some Issues in Agrarian and Ecological Economics, in Memory of Georgescu-Roegen.” Ecological Economics 22 (3): 225-238.

Miernyk, William H. 1990. “A Mind Ahead of its Time.” Libertas Mathematica 10: 5-26.

Mirowski, Philip. 1992. "Nicholas Georgescu-Roegen.” In Warren Samuels, ed., New Horizons in Economic Thought. Aldershot: Edward Elgar, pp. 86-105.

Missemer, Antoine. 2013. Nicholas Georgescu-Roegen, pour une révolution bioéconomique. Lyon: ENS Éditions.

Missemer, Antoine. 2017. "Nicholas Georgescu-Roegen and Degrowth." The European Journal of the History of Economic Thought 24 (3): 493-506. 
Nurkse, Ragnar. 1953. Problems of Capital Formation in Underdeveloped Countries. Oxford: Basil Blackwell.

Rosenstein-Rodan, Paul. 1943. "Problems of Industrialisation of Eastern and South-Eastern Europe.” The Economic Journal 53 (210/211): 202-211.

Rosenstein-Rodan. Paul. 1944. "The International Development of Economically Backward Areas." International Affairs 20 (2): 157-165.

Schultz, Theodore W. 1956. "The Role of Government in Promoting Economic Growth.” In L.

D. White, ed., The State of the Social Sciences. Chicago: University of Chicago Press, pp. 372383.

Seers, Dudley. 1963. "The Limitations of the Special Case." Bulletin of the Oxford Institute of Economics and Statistics 25(2): 77-98.

Sivakumar, S. S. 2010. “The Unfinished Narodnik Agenda: Chayanov, Marxism, and Marginalism Revisited." The Journal of Peasant Studies 29 (1): 31-60.

Suprinyak, Carlos E. \& Fernandez, Ramón G. 2021. “The 'Vanderbilt Boys' and the Modernization of Brazilian Economics.” History of Political Economy [forthcoming].

Thorner, Daniel. 1969. “Old and New Approaches to Peasant Economies.” In Clifton Wharton, ed., Subsistence Agriculture and Economic Development. New Brunswick and London: AldineTransaction, pp. 94-99.

Vivien, Franck-Dominique. 1999. “From Agrarianism to Entropy: Georgescu-Roegen's Bioeconomics from a Malthusian Viewpoint.” In Kozo Mayumi and John Gawdy, eds., Bioeconomics and Sustainability: Essays in Honor of Nicholas Georgescu-Roegen.

Cheltenham, UK and Northampton, MA, USA: Edward Elgar, pp. 155-172.

Warriner, Doreen. 1939. Economics of Peasant Farming. London: Oxford University Press. 